\title{
New species and a new combination in Pycnosorus (Asteraceae: Gnaphalieae)
}

\author{
J. Everett and A.N.L. Doust
}

\begin{abstract}
Everett, J. and Doust, A.N.L. (National Herbarium of New South Wales, Royal Botanic Gardens, Sydney, NSW Australia 2000) 1992. New species and a new combination in Pycnosorus (Asteraceae: Gnaphalieae). Telopea 5(1): 39-43. The genus Pycnosorus Benth. is reinstated, the new species Pycnosorus eremaeus, P. melleus and P. thompsonianus are described and the new combination P. pleiocephalus (F. Muell.) Everett \& Doust is made. Notes on the flowering periods, habitat and general distribution are included.
\end{abstract}

\section{Introduction}

In the course of revising Craspedia (Asteraceae) in Australia we have concluded that the species fall into two generic groups, and consequently we are re-establishing the genus Pycnosorus Bentham, to include the six species with sessile capitula. Two species have been published under Pycnosorus, P. globosus Benth. and P. chrysanthes (SchldI.) Sond. [as chrysanthus]; one species has been published only under Craspedia, C. pleiocephala F. Muell.; three species were undescribed, one of these from New South Wales. Formal names for the N.S.W. species are required for use in the forthcoming Flora of New South Wales. Here we describe the three new species and make the new combination.

We have decided to reinstate Pycnosorus because it differs from Craspedia primarily by having sessile partial heads and yellow bracts, paleae and pappus hairs. This separation is supported by chromosome counts for P. pleiocephalus of $n=6$ (Short 1986) and for C. uniflora of $n=11$ (Turner 1970, Beuzenberg \& Hair 1984), although further counts are needed to confirm this apparent distinction.

Short et al. (1989) compared single specimens of two taxa, Pycnosorus aff. pleiocephalus and Craspedia uniflora s.l., and noted some differences in crystal occurrence in the pericarp, but this needs to be confirmed by further work. A detailed discussion of these and other characters, and of the taxonomic relationships, will appear in a separate paper. All specimens cited have been seen unless otherwise indicated.

\section{P. pleiocephalus (F. Muell.) Everett \& Doust, comb. nov.}

BASIONYM: Craspedia pleiocephala F. Mueller (1852: 404).

TYPE: SOUTH AuSTRALIA: Flinders Ranges: At the eastern side of the Flinders Range, in the flat parts and on lower hills toward Mount Brown [An der ostseite des Flindersgebirges in der Ebene und auf niedern Hügeln, auf Mount Brown zul, F. Mueller s.n., Oct 1851 (holo MEL 612328).

Ascending or erect herb with many stems to $40 \mathrm{~cm}$ high from a woody taproot. Basal leaves withering early, leaves mainly cauline oblong to oblanceolate, 3-7 cm long, 2$10 \mathrm{~mm}$ wide, decreasing in length up the stem to $1 \mathrm{~cm}$ long, broad-acute, glandtipped, concolorous, olive-brown to green, with glandular hairs and coarse multiseptate hairs especially on the margins. Inflorescence a single ovoid or globose com 
pound head or of one main compound head, branched below or from the centre, giving rise to smaller secondary globose heads. Main compound head 10-20 mm long, 10-15 mm diam., with up to 50 partial heads. Partial heads sessile, each with 46 florets; main bract of the partial involucre ovate, with a broad yellow hyaline margin and a small linear to narrow-ovate brown herbaceous and glandular stereome, very finely ciliate overall. Corolla lemon-yellow; lobes narrow-acute, inconspicuously papillate on the inner surface; achenes 1.5-2 mm long, 1-1.5 mm diam., with long, appressed dense silky hairs; pappus of 8-15 plumose bristles $2-4 \mathrm{~mm}$ long, yellow at least at the tip, the tips brush-like.

FLOWERING PERIOD: Mostly early spring-early summer, but can be found flowering at any time of the year, probably dependent on time of rainfall.

HABITAT: Often in wet sandy or clayey depressions but also on stony ridges. In mallee and chenopod shrubland.

DISTRIBUTION: Mainly in areas associated with the Murray-Darling drainage system and with the catchment area for Lakes Eyre and Frome.

Selected SPecimens: New South Wales: South Western Plains: Yathong, Mt Hope, Milthorpe 2605 E Cunningham, 17 Aug 1974 (NSW). North Far Western Plains: $0.2 \mathrm{~km}$ SE of Mt Wood homestead, Sturt NP, Denham 054, 17 Sep 1989 (NSW). Victoria: Pirta, Far NW, Beauglehole 39495, 12 Sep 1960 (MEL). South Australia: c. $2 \mathrm{~km} \mathrm{~W}$ of turnoff to Uno Homestead, Gawler Ranges, Conn 3115 \& Scott, 11 Sep 1989 (NSW, AD n.v., MEL, MO n.v.); between Frome Downs Homestead and Black Oak Bore, Weber 2108, 24 July 1971 (AD, SYD n.v., NT n.v.).

\section{Pycnosorus eremaeus Everett $\mathcal{E}$ Doust, sp. nov.}

Pycnosoro pleiocephalo similis sed margine bracteae principalis involucrorum partialium haud scarioso, indumento albolanato foliorum et capitulorum compositorum immaturorum, differt.

TYPE: QuEENSLAND: Gregory South: Coopers Creek, Windorah, $25^{\circ} 22^{\prime} \mathrm{S} 142^{\circ} 43^{\prime} \mathrm{E}$, alt 100 metres, P.G. Wilson $400 \&$ \& R. Pickering, 24 Sep 1989 (holo NSW; iso BRI, AD).

Ascending or erect herb with few to many stems to $35 \mathrm{~cm}$ high from a woody taproot. Leaves mainly cauline, linear-ovate to narrow-spathulate, attenuate, $2-6 \mathrm{~cm}$ long, 2$6 \mathrm{~mm}$ wide, decreasing in length upwards; leaves with glandular hairs and coarse multi-septate hairs on the upper surface, and with glandular hairs, coarse multiseptate hairs, or more or less dense fine woolly hairs below, fine woolly on margins, often making a distinct white margin to the leaf; lower leaves with mucronate glandular tip, upper leaves with hyaline to pale brown membranous tips to $2 \mathrm{~mm}$ long. Inflorescence a single ovoid or globose compound head, or of one main compound head, branched below or from the centre, giving rise to smaller secondary globose heads. Main compound head 7-25 mm long, 6-13 mm diam., mostly less than twice as long as broad, densely woolly at least when young, with 50-100 partial heads. Partial heads sessile, each with 5-8 florets; main bract of the partial involucre narrow-ovate, with a brown herbaceous stereome, with glandular and fine woolly hairs below, and an acuminate membranous tip not extending down the margins of the stereome. Corolla golden-yellow; lobes narrow-acute, inconspicuously papillate on the inner surface; achenes 1-2 mm long, 0.5-1 mm diam., with long appressed white to pink silky hairs; pappus of 9-15 plumose bristles, $1.5-3 \mathrm{~mm}$ long, yellow at least at the tip, the tips brush-like.

Distinguished from $P$. pleiocephalus by the white woolly indumentum of the leaves and immature flowering heads, and in the main bract of the partial involucre lacking a scarious margin. 
DERIVATION: From the Greek eremos, meaning solitary, referring to the remote inland distribution.

FLOWERING PERIOD: Winter to early summer, probably dependent on time of rainfall.

НАвітAт: Found on mostly heavy or rocky soils.

Distribution: A large area of Central Australia.

Selected sPeCimens: NoRTHern TerRitory: 17 miles [27 km] WNW of Rankine River Police Station, Perry 1552, 18 June 1948 (NSW, BRI, CANB, MEL, AD, NT). QueENSLAND: WARLUS VI Site H69, $27 \mathrm{~km}$ WNW of 'Marion Downs', Purdie 1437, 8 Sep 1978 (BRI); approx. $7 \mathrm{~km} \mathrm{SE}$ of 'Davenport Downs' station, Aston 2042, 18 Aug 1980 (BRI, MEL, AD). South Australia: Bloods Creek, Lothian 4617, 26 July 1968 (AD); Margaret Creek, Alcock 6477, 3 Oct 1978 (AD, COLO n.v.).

\section{P. melleus Everett \& Doust, sp. nov.}

Pycnosoro pleiocephalo similis sed inflorescentia composita cylindrica pallidiore differt.

TYpe: SOuth Australia: Lake Eyre Basin: Between Birdsville and Cadelga c. $90 \mathrm{~km}$ from Bluff (Roseberth) Homestead, Miranda track, swamp flat, T.R.N. Lothian 593 E D.E. Francis, 29 Aug 1960 (holo AD 96045011; iso CANB, NY n.v., W n.v., L n.v., Tripoli n.v.).

Ascending or erect herb with few to many stems to $25 \mathrm{~cm}$ high from a woody taproot. Leaves mainly cauline, linear to narrow-ovate, $1-3.5 \mathrm{~cm}$ long, 2-5 mm wide, decreasing in length upwards; leaf hairs long and short glandular above and below, fine woolly below, fine woolly on the margins; lower leaves with mucronate glandular tip, upper leaves with hyaline to pale brown membranous tips to $2 \mathrm{~mm}$. Inflorescence a cylindrical compound head, 8-38 mm long, 5-11 mm diam., mostly more than twice as long as wide; 50-120 partial heads. Partial heads sessile, with 4-6 florets; main bract of the partial involucre narrow-ovate, with a brown clavate herbaceous stereome, with glandular and fine woolly hairs below, surrounded by a \pm narrow membranous margin and surmounted by an acuminate membranous tip. Corolla yellow; lobes narrow-acute, inconspicuously papillate on the inner surface; achenes $0.5-1.1 \mathrm{~mm}$ long, with long appressed pink to rust coloured silky hairs; pappus of 9-12 plumose bristles, pale yellow at least at tip, the tips brush-like.

Distinguished from other Pycnosporus species by the cylindrical compound heads and by the heads being a pale honey colour.

DERIVATION: From the Latin melleus meaning honey-coloured or honey-like; referring to the pale honey-yellow colour of the compound head, which is different from the darker, golden colour of other Pycnosorus species.

FLOWERING PERIOD: Winter to early summer, probably dependent on time of rainfall.

HABITAT: Found on dry watercourses and alluvial flats.

DistRIBUTION: Restricted to a small area on the Queensland-South Australia border.

Selected SPECIMENS: QueEnsLAnd: Birdsville, Blake 12219, 19 Jul 1936 (BRI), Boyland 177, 20 Sep 1966 (BRI); Mulligan River, Clarke, ? 9 Sep 1904 (NSW 220836). South AustraLIA: c. $110 \mathrm{~km}$ SSW of Birdsville, Riederer s.n., 2 Sep 1962 (AD 966070714, E n.v., G n.v., M n.v., AAU n.v.); Goyders Lagoon, S.A. Pastoral Board, 23 June 1953 (AD 97930189). 


\section{P. thompsonianus Everett $\mathcal{E}$ Doust, sp. nov.}

Pycnosoro chrysantho similis sed foliis concoloribus, margine bracteae principalis involucrorum partialium scarioso, differt.

TyPE: New South Wales: South Far Western Plains: Junction of north crossroad \& River Drive, $\mathrm{N}$ of Ranger Station, Kinchega National Park, $32^{\circ} 27^{\prime} \mathrm{S}, 142^{\circ} 22^{\prime} 30^{\prime \prime} \mathrm{E}, \mathrm{A}$. Denham 042, 12 Sep 1989 (holo NSW; iso BRI, AD, DNA).

Ascending or erect herb with woody stems to $35 \mathrm{~cm}$ high, branching at the base from a woody taproot. Basal leaves withering early, leaves mainly cauline, linear, mostly 1-5 cm long, 1-5 mm wide, occasionally to $10 \mathrm{~cm}$ long, broad-acute, concolorous, white to grey, with dense, appressed, fine woolly hairs; lower leaves gland-tipped, uppermost leaves with a lanceolate golden hyaline tip, although this occasionally caducous. Inflorescence a globose or slightly ovoid compound head. Compound head 4-12 mm diam., with c. 45-100 partial heads. Partial heads sessile, with 3-6 florets; main bract of the partial involucre with a narrow-ovate, brown, stiffly herbaceous and glandular stereome, with dense, woolly hairs, and an acuminate yellow membranous tip. Corolla golden-yellow; lobes acute, inconspicuously papillate on the inner surface; achenes 1-1.5 $\mathrm{mm}$ long, c. $0.5 \mathrm{~mm}$ diam., with long appressed dense silky hairs; pappus of 12-14 plumose bristles $1.5-2.5 \mathrm{~mm}$ long, yellow at least at the tip, the tips brush-like.

Distinguished from $P$. chrysanthes by the concolorous leaves not contrasting with the white-woolly stems, and by the main bract of the partial involucre possessing a scarious margin. This species was referred to as Craspedia sp. P in Jacobs \& Pickard (1981).

DERIVATION: In honour of Joy Thompson, a colleague at NSW whose collections from the semi-arid interior of New South Wales have added to our knowledge of Pycnosorus and whose detailed acquaintance with the alpine areas of New South Wales has clarified the taxonomy of Craspedia.

FLOWERING PERIOD: Early spring to early summer but also dependent on time of rainfall.

HABITAT: Usually on heavy soils, on floodplains, in chenopod shrubland, occasionally on red sandy ridges.

Distribution: The western and far western plains of New South Wales and southwestern Queensland.

Selected SPECIMENS: QueEnSLAND: 36 miles [56 km] S of Wyandra, Williams 90, 25 Sep 1968 (BRI). New South WALEs: North Western Plains: $27 \mathrm{~km}$ SE of Collerina towards Brewarrina, Dunlop 920 , 25 Aug 1969 (CBG); 2 km NW Louth on Bourke road, Cunningham 2872, 2 Sep 1972 (NSW). South Western Plains: c. $35 \mathrm{~km}$ NW of Hay along road to Thelangerin, James 424, 10 Oct 1983 (NSW); Woorandara Station near Booligal, Canning 3574, 30 Sep 1973 (CBG). North Far Western Plains: $2 \mathrm{~km}$ SE of Eagle Tank on Twelve Mile Ck floodout, Denham 048, 15 Sep 1989 (NSW, PERTH).

\section{Acknowledgements}

We wish to thank Andrew Denham for his assistance particularly in the collection of numerous western New South Wales specimens and for his observations in the early stages of this project when the reinstatement of Pycnosorus was first proposed. Thanks are also due to Karen Wilson for the Latin diagnoses, and to Leonie Stanberg, Ross Rowe and Dianne Godden for technical assistance. We are grateful to the Heads of AD, PERTH, BRI, DNA, MEL, CANB, CBG, and HO for the loan of specimens that have made this study possible. The work has been in part supported by grants from the Australian Biological Resources Study which we gratefully acknowledge. 


\section{References}

Beuzenberg, E.J. \& Hair, J.B. (1984) Contributions to a chromosome atlas of the New Zealand flora - 27 Compositae. New Zealand Journal of Botany 22: 353-356.

Jacobs, S.W.L. \& Pickard, J. (1981) Plants of New South Wales (Government Printer: Sydney).

Mueller, F. (1852) Diagnoses et descriptiones plantarum novarum, quas in Nova Hollandiae australi praecipue in regionibus interioribus. Linnaea 25: 367-445.

Short, P.S. (1986) In Löve, A. (ed.), Chromosome number report XCII. Taxon 35: 610.

Short, P.S., Wilson, K.E. \& Nailon, J. (1989) Notes on the fruit anatomy of Australian members of the Inuleae (Compositae). Muelleria 7(1): 57-79.

Manuscript received 5 November 1991

Manuscript accepted 13 March 1992 